\title{
Formation of an Innovative Competitiveness Management System of the Enterprise: On the Case of Ukraine's Healthcare
}

\author{
Serhii Makarenko ${ }^{1}$, Nataliia Oliinyk ${ }^{2}$, Vladyslav Danko $^{1} \&$ Yevheniia Kaplina ${ }^{1}$ \\ ${ }^{1}$ Department of Management and Administration, Kherson State University, Kherson, Ukraine \\ ${ }^{2}$ Department of Economics, Entrepreneurship and Economic Security, Kherson National Technical University, \\ Ukraine \\ Correspondence: Dr. Serhii Makarenko, Departement of Management and Administration, Kherson State \\ University, Kherson, Universitetska street, 27, Ukraine. E-mail: makar0684@gmail.com
}

Received: December 30, 2019; Accepted: January 17, 2020; Published: January 21, 2020

This research was supported by the Kherson regional organization of the trade union of textile and light industry workers and the primary trade union organization of "Kherson Cotton Factory".

\begin{abstract}
In modern conditions, the priority task for Ukraine is the institutional transformation of the economy, the main purpose of which is to ensure sustainable socio-economic development. The article discusses the theoretical and methodological foundations and develops scientific and practical recommendations for the formation of an innovative competitiveness management system based on the example of healthcare institutions in Ukraine. Based on the analysis, the main characteristics of the innovative development of health care institutions are determined, interaction schemes for participants in the innovation process in the health care system and the mechanism for developing and implementing competitive strategies in the health care institution management system are developed. The calculation of the integral indicator of assessing the effectiveness of the use of labor resources as the most important component of assessing the level of competitiveness of an enterprise.
\end{abstract}

Keywords: management, innovation, competitiveness, integral indicator, labor resources

\section{Introduction}

With the spread of market mechanisms in economic systems, the introduction of effective tools for managing social institutions is becoming more and more urgent. This issue is very sensitive in medicine. The development of medicine is one of the main indicators of the country's sustainable development. Other areas of economic activity cannot be fully developed if the healthcare system is lacking. Without effective control of epidemics and the protection of the population against disease, people will not be particularly interested in the minor needs, since the need for health will be paramount.

The specificity of doing business in the health care field requires a specific approach in view of the specific features of the marketed product - medical services. The result of innovation in health care is the development of medical technologies, research and updated practices aimed at obtaining a qualitatively new idea of health improvement, treatment, process management in the medical field, obtaining new medical products, technologies or services with competitive advantages.

A health care innovation process is a sequential chain of events that transforms an idea from an idea to a specific product, technology or service and is used in practice to achieve general medical goals. Innovation is not only about the provision of medical services, but also the organization of teamwork, so there is a need to reengineer the processes of functioning of the medical institution.

The reengineering of medical business processes can only be successful if the prerequisites and the lack of humanrelated problems have been resolved. At the same time, management's lack of awareness of the wide range of available alternatives and insufficient financial resources make it difficult to disseminate client-oriented modern process technologies, which does not allow for the introduction of fundamental changes by selecting appropriate combinations of new information technologies that are only fully known to the market. 
The methodological aspects of business process modeling must meet the requirements of strategic management, taking into account the specific features of each enterprise and being based on the principles of project management, such as teamwork, systematic approach, process approach, quality management system, balanced scorecard and the principle of continuous improvement.

At every functional level, managers must set their own goals and benchmarks, which unfortunately has not yet been done in many healthcare settings. Insufficient clarity in the vision of the nature of the activity often does not allow the management of the medical institution to identify key goals, to form a hierarchy of priorities, to plan the development of services and related services. The application of business process-oriented management in the healthcare sector not only helps overcome urgent problems, but also opens up new prospects for development. However, the implementation of technologies such as a plan in healthcare institutions is complicated by a number of factors that impede the widespread implementation of a process approach to management, in particular, the reluctance of employees to go beyond their narrow specialization. Therefore, the study of the specifics of management and features of the development of healthcare institutions in the example of Ukraine is an urgent and promising direction of many scientific researches.

The purpose of the article is to study the theoretical and methodological foundations and to develop scientific and practical recommendations for the formation of an innovative system for managing the competitiveness of the enterprise on the example of health care institutions in Ukraine.

The methodological basis of the research was the scientific works of Ukrainian and foreign scientists, leading experts, statistical and analytical materials of state authorities. The results are obtained through the use of methods: expert - to identify the impact of qualitative and quantitative indicators on the efficiency of use of labor resources; economic and mathematical - to determine the integral indicator of the assessment of the efficiency of the use of labor resources; abstract-logical - for theoretical generalization and formulation of conclusions.

\section{Literature Review}

In today's market conditions, the need to ensure stable development and competitiveness of domestic enterprises encourages entrepreneurs and managers to find effective systems and methods of managing economic activity. According to M. Porter (2005), an enterprise's competitiveness is an opportunity to gain competitive advantage and retain them in certain areas. A. V. Savchuk (2001) points out that the competitiveness of an enterprise is manifested in the ability to achieve the best results in a competitive market, in a certain activity.

In our opinion, the concept of competitiveness of economic entities should be understood as the ability of an economic entity to respond adequately to changes in the external and internal business environment in order to ensure profitability at least at the industry level. One of the internal factors of sustainable socio-economic business development and increase of its competitiveness is activation of innovative activity. Innovative activity of the enterprise should be based on the principles of priority of innovative development, scientific novelty, feasibility study, legal substantiation, minimization of risk and increase of competitiveness of both products, works, services, and the enterprise as a whole. The innovation activity of enterprises, including healthcare institutions, has long been a key condition for their competitiveness and requires systematic management.

The development of the healthcare system and the formation of the market of medical services in Ukraine, as well as in many other countries of the world, is based on theoretical and methodological achievements of world and national science and not only medical, but also economic, sociological, geographical, etc. According to the views of A.H. Akhlamov, \& N.L. Kusyk (2011) management of healthcare institutions should be considered from two points: healthcare management is the process of influencing material, labor and financial relations, their organization for the implementation of economic and social policy of a healthcare institution; healthcare management is the totality of all bodies of the management apparatus of a healthcare institution and their management actions.

Research by A.V. Feigenbaum, \& D.S. Feigenbaum (2009) argues that the dynamics of the development of medicine, namely innovative methods of prevention, diagnosis and treatment, exceed the development of technology in many other fields, due to its high adaptability, close relationship with science and the impact of the human factor in medicine.

In recent years, there has been a large increase in regulatory and programmatic initiatives to promote diffusion and transfer of medical innovative technologies in developed countries. Particular attention is paid not only to specific regulatory measures to accelerate technology dissemination and enhance communication between technology developers and users, but also to create and support assistive systems and infrastructures for technology dissemination (Andreeva YL, 2009; Beliakov VK, \& Pyven DV, \& Antonov DP, 2008; Byrher EV, 2007). 
In Ukraine, this problem has been studied in terms of implementation and evaluation of the effectiveness of innovative projects in the healthcare system (Karamyshev DV, \& Nemchenko AS, 2006; Androshchuk HO, \& Zhyliaiev IB, \& Chyzhevskyi BH, \& Shevchenko MM, 2009), legal aspects innovation (Spasibo-Fatieieva I., 2005), public policy on social innovation in healthcare, quality management of higher medical education, humanitarian, social and economic priorities of innovative development (Bilynska MM, 2002; Bodak VM, 2004; Pashkov VD , 2006; Skurativskyi V., 2003).

It should be borne in mind that the modern scientific world focuses specifically on the health care economy, which is linked, above all, to the rising cost of maintaining medical infrastructure and scarce healthcare resources to meet the rapidly growing needs of the healthcare community. The socio-economic conditions of today are driven by market relations and require a more objective account of the costs and outcomes of the network of health care facilities. Therefore, the formation of objective innovative systems for managing the competitiveness of the enterprise, including in the field of health care, as a basis for the rational use of production resources to maximize satisfaction of the needs of the population in medical care, is of particular relevance and defines the purpose of the research.

\section{Results}

\subsection{Features of Innovative Development of Healthcare Institutions}

Innovation in the management of healthcare facilities is the result of innovative activities implemented in the form of modernization of material and technical base, introduction of the latest progressive means and methods of treatment, medical technologies, medical products and medicines, improvement of existing methods of diagnostics and treatment (medical innovations), development of software tools for information processing, creation of new models of functioning of health care institutions and staff development. It is advisable to characterize the innovative development of healthcare institutions as a new model of organization and provision of accessible healthcare services based on innovation, characterized by the adoption of strategic decisions in innovation at all hierarchical levels of the national economy. Innovative development of the healthcare sector is a dynamic process of structural improvement of the sphere due to the implementation of the latest knowledge in order to improve the quality of medical services, increase the competitiveness of healthcare entities with a focus on innovative transformations. The innovative development of the healthcare sector is a significant and costly matter for the state that needs constant improvement in order to improve its functioning and ensure the fulfillment of its social functions. The characteristics of innovative development of health care facilities are shown in Table 1.

Table 1. Characteristics of innovative development of healthcare institutions

\begin{tabular}{ll}
\hline Criteria & Characteristic \\
\hline Elements of social & - creation of a system of strategic management of innovative development of health care \\
function & institutions of Ukraine; \\
& - increasing the volume of scientific development at the expense of commercial structures; \\
& - conducting sociological and statistical surveys in order to assess the needs of society for \\
& innovation, in particular medicines; \\
& - state control over the provision of the necessary quality medical services of the whole \\
& population; \\
& - defining a legally clear list of medical care to be provided free of charge in public health \\
& care facilities and with adequate funding for these facilities; \\
& - creating links between health care funding at the expense of state and local budgets and \\
& the end results of their work; \\
& - raising the level of funding for health care institutions through the development and \\
& implementation of a public-private partnership mechanism; \\
& - regulatory development of Ukrainian medical standards in accordance with international \\
& standards of quality of medical services; \\
& - introduction of compulsory health insurance of citizens. \\
\hline of & - the main subject is the implementation, use and commercialization of the results of \\
& research and development in production and social sphere; \\
innovative activity & - Intangible benefits are the object - the results of intellectual activity that are brought to a \\
of healthcare & state of innovative product and implemented as innovation; \\
& - the results have a long-term character; \\
& - a high degree of unpredictability of the consequences and results, which indicates their \\
\hline &
\end{tabular}


risk character;

- provides for the financing of works on the implementation of an innovative project for the implementation and use of the results of research and development, that is, accompanied by the investment of funds in intangible objects, which is in fact another element of the subject of innovation;

- causes positive socio-economic changes;

- One of the results of their implementation is to increase the competitiveness of the entities of the health care industry and the products or medical services that they provide or provide on the basis of innovation

The innovative approach to the management of healthcare facilities is based on systemic transformations in the industry, combining the formation of innovative infrastructure, innovative financial and economic mechanism, as well as accounting, analytical, regulatory, methodological and information support, which allow to improve quality, accessibility health care and the effectiveness of health care resources.

It is necessary to apply project management to the medical sector for the development of the healthcare system and healthcare institutions, including public-private partnerships, effective investment management, aimed at achieving the desired result both in terms of population health and quality work of healthcare institutions.

The activities of the medical sector should be organized, focusing on the development of innovations in the functioning of the healthcare system, improving existing business processes and ensuring the development and implementation of projects for the creation of new medical projects based on project management tools (Figure1).

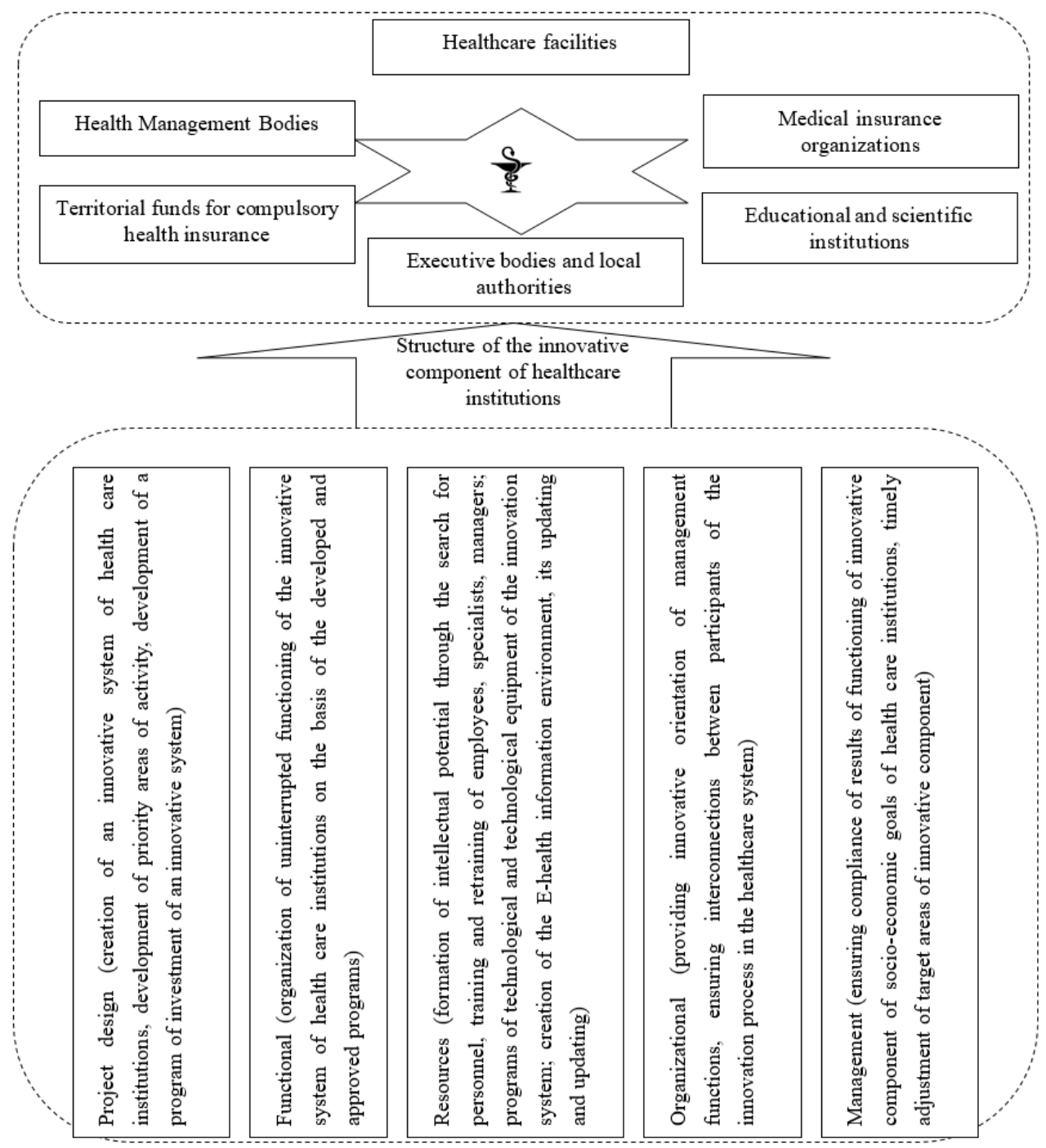

Figure 1. The scheme of interaction of participants of the innovation process in the healthcare system 
The success of innovation management depends on the ability to create stimulating internal and external framework conditions for innovation. The innovation process requires strategic planning and market-oriented management.

In today's unstable external and internal business environment, participants in the innovation process in the healthcare system must constantly develop and implement appropriate innovation development strategies. Offered in Fig. 1 Scheme will allow to provide organic interaction of a multifaceted complex of accelerated technical, technological, organizational, economic and individual transformations, formation of scientific and technical potential, sufficient for development and application of new technologies of providing medical services, practical implementation of which will provide all participants with a sufficient level of competitiveness.

The functioning of the modern healthcare system of Ukraine in the conditions of market relations and rather limited primary healthcare facilities in the healthcare institutions of the existing material, financial and human resources requires the development of measures to increase the efficiency of their use. In this regard, problems of an organizational and economic nature arise, one of which is the planning and management of the development and implementation of medical innovations aimed at satisfying consumers with the quality of new medical care technologies and increasing the efficiency of healthcare institutions. Of course, focusing on the most optimal quality final results, attention should also be focused on rationalizing the use of available resources. Quality should be the goal of managing this process in the development and implementation of any new medical technology as part of a comprehensive integrated innovation cycle.

To implement these tasks, it becomes necessary to develop practical recommendations for the management of healthcare institutions with a clear and science based algorithm of actions for managing the introduction of modern innovative technologies in the activities of medical organizations as the basis for increasing their competitiveness. The complexity of the development of such measures is due to the lack of general recommendations on specific technologies for managing this process in health facilities in a market environment.

Proposed in Figure 2, the mechanism for the development and implementation of competitive strategies in the management system of healthcare institutions provides for the study of the conditions under which the chosen strategy provides the company with competitive advantages in the medical services market, namely: the adequacy of the organizational structure and the introduction of strategic management systems in institutions; developing a matrix of the distribution of functions between the subsystems of the institution and determining the interdependence between them; the formation of creative thinking among program performers; the ability of specialists in each subsystem to determine alternative options for achieving the necessary results; determination of a real assessment of competitors; availability of sufficient resource potential; modern technological and a sufficient level of access to the information environment E-health.

The development of competitive strategies enables healthcare institutions to obtain sustainable competitive advantages through intense competition, to satisfy the needs of consumers of medical services based on innovative technologies better than competitors do. It is worth noting that the model of the introduction of medical innovative technologies should be based on the application of an integrated approach to the provision of medical care, based on the principles of comprehensive extended, coordinated, preventive medical care and health promotion, focused on the needs of the patient, his family and society.

\subsection{Methodology for Assessing the Effectiveness of Functioning and the Level of Enterprise Competitiveness}

One of the most important components in the development and justification of the feasibility of implementing competitive marketing strategies is an objective assessment of the level of competitiveness of the enterprise and its individual components.

High competitiveness of the enterprise is determined by the presence of the following features:

- consumers are satisfied with the products (work, services) of this enterprise (the beneficial effect of consumption has reached a maximum) and are ready to re-acquire (receive) it

- employees are proud of their participation in the activities of the enterprise and consider it an honor to work on it;

- shareholders (partners), the community of the region have no claims to the company.

In order to become a competitive enterprise it is necessary:

- ensure the competitiveness of products, work performed, services rendered in target market segments. By the competitiveness of a product is meant the consumer's assessed property of an object to surpass at a certain point 
in time in quality and price characteristics analogues in a particular market segment without prejudice to the manufacturer;

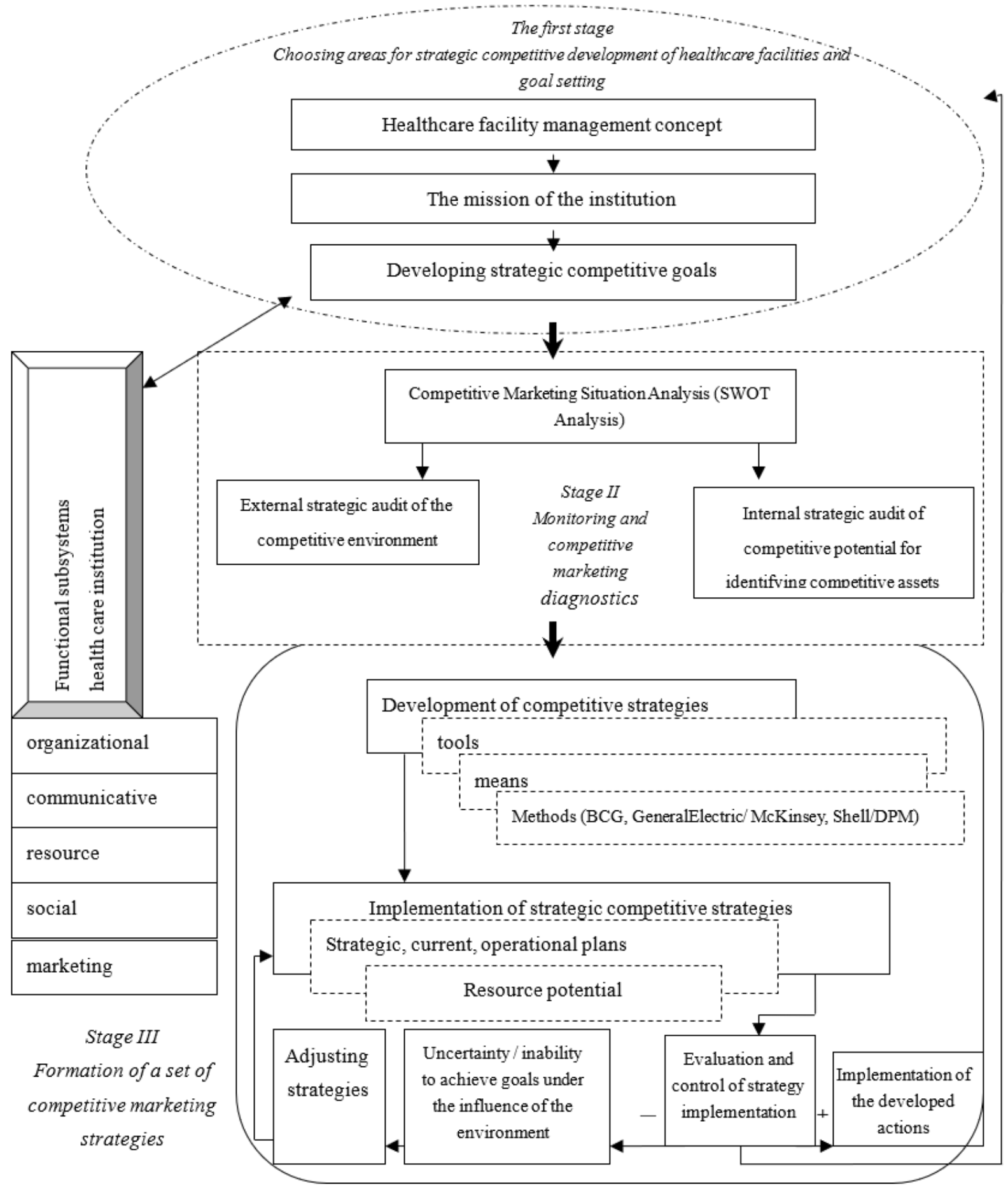

Figure 2. Scheme of the mechanism for the development and implementation of competitive strategies in the management system of a healthcare institution

- raise the potential of competitiveness of the enterprise, and therefore its units, to the level of global manufacturers in this industry. This indicator characterizes the ability of the organization to work successfully in the future. 
In managers, the natural question arises of evaluating their enterprise compared to competitors. Determining your place in the market is the first step in managing the competitiveness of an enterprise; it is an objective justification for choosing an appropriate strategy for further functioning.

To manage competitiveness, an objective assessment tool is required. An error in choosing a measurement method can lead to the adoption of erroneous management decisions. To date, there is no generally accepted methodology for assessing the competitiveness of enterprises. Each company evaluates its competitive position by its own methodology, and does not advertise the essence and effectiveness of its application.

Assessing the competitiveness of an enterprise is a complex multifactorial task, which boils down to identifying the most significant numerical indicators of competitiveness and their integration. The need to aggregate all indicators is due to the fact that the object of modeling (the effective functioning of the enterprise) requires not only generalizing characteristics, but also the ordering of its individual elements according to certain properties and principles. It is possible to implement this mechanism using the integrated assessment method, which can be based on parameters obtained by analyzing the main components of the effective functioning of the enterprise. Based on an integrated assessment, it is possible to comprehensively evaluate the financial and economic activities of an enterprise, identify shortcomings in work, and propose development directions. In addition, the integral assessment is the basis for predicting the effective functioning of the enterprise, since the adequacy of the forecast data depends on the reliability of the input information.

According to the views of N.V. Lepetiukha, \& I.O. Rudska (2016) the methodology for assessing the effectiveness of the functioning of the enterprise, the level of its competitiveness and the calculation of the integral assessment should be carried out in several stages:

- Stage 1 - the formation of a system of information space for assessing the effectiveness of an enterprise. The main stage in determining the integral assessment for making managerial decisions is the formation of an information space system that should ensure the objectivity, richness, depth and adequacy of information characterizing the studied socio-economic phenomena and processes. From the correct analytical choice, reliability and construction of a system of indicators depends on the objectivity of an integrated assessment of the effectiveness of the enterprise. If the selection of many indicators for diagnosing the state of control objects is not carried out correctly, then no matter how well this information has been worked out, the data will be of poor quality. The formation of an information space system means by itself the formation of a matrix of input data $X=\left(\mathrm{x}_{\mathrm{ij}}\right)$, where $x i j$ is the value of the $\mathrm{j}$-th indicator for the $\mathrm{i}$-th object;

- Stage 2 - a matrix of standardized attribute values. Since indicators can have different nature and values that are incomparable with each other, data are standardized. To do this, change the matrix $\mathrm{X}$ to the matrix Z. Elements of the matrix $\mathrm{Z}$ are calculated by the formula:

$$
Z_{i j}=\frac{x_{i j}-x_{a v . j}}{\delta_{j}},
$$

where $\mathrm{x}_{\mathrm{av} . \mathrm{j}}$ - is the average value of the $\mathrm{j}$-th indicator;

$\delta_{j}$ - standard deviation of the $j$-th indicator.

- Stage 3 - the formation of a "reference point". To do this, all variables must be divided into stimulants and destimulators. The basis for the distribution of signs into two groups is the nature of the influence of each of them on the level of efficiency of the enterprise. Signs that positively affect the indicator are stimulants, in contrast to signs that negatively affect the indicator and therefore are destimulants. The distribution of signs on stimulants and destimulators is the basis for the formation of a reference point, which is a point $P_{0}$ with coordinates $Z_{01}, Z_{02}, Z_{0 n}$;

- Stage 4 - calculation of the Euclidean distance. The distance between the individual unit points and the point $\mathrm{P}_{0}$, representing the reference point, $\mathrm{C}_{\mathrm{i} 0}$ is calculated by the formula:

$$
\mathrm{C}_{\mathrm{i} 0}=\sqrt{\sum_{\mathrm{j}=1}^{\mathrm{n}}\left(\mathrm{Z}_{\mathrm{ij}}-\mathrm{Z}_{0 \mathrm{j}}\right)^{2}},
$$

The obtained distances are the initial values that are used in the calculation of the integral indicator.

- Stage 5 - calculation of the values of the integral indicator $\left(\mathrm{d}_{\mathrm{i}}\right)$ using the formulas: 


$$
\mathrm{d}_{\mathrm{i}}=1-\frac{\mathrm{C}_{\mathrm{i} 0}}{\mathrm{C}_{0}},
$$

Where

$$
\begin{gathered}
\mathrm{C}=\mathrm{C}_{\mathrm{av} .0}+2 * \mathrm{~S}_{0}, \\
\mathrm{C}_{\mathrm{av} .0}=\frac{1}{\mathrm{~m}} * \sum_{\mathrm{i}=1}^{\mathrm{m}} \mathrm{C}_{\mathrm{i} 0}, \\
\mathrm{~S}_{\mathrm{O}}=\sqrt{\frac{1}{\mathrm{~m}} \sum_{\mathrm{i}=1}^{\mathrm{m}}\left(\mathrm{C}_{\mathrm{i} 0}-\mathrm{C}_{\mathrm{av} .0}\right)^{2}},
\end{gathered}
$$

The closer the value of $d_{i}$ is to one, the higher the level of the indicator being evaluated.

- Step 6 - Drawing conclusions based on the data obtained - the last step in the presented algorithm.

The proposed methodology can be used both for the overall assessment of the performance and competitiveness of the enterprise, and for evaluating its individual component. Considering that labor resources are the most important element without which the effective functioning of healthcare institutions in Ukraine and the provision of quality medical services is impossible, the example of a leading enterprise operating in the field of health care (Kherson, Ukraine) was carried out integral indicator of labor efficiency.

To determine the indicators that will be used to evaluate the efficiency of the use of labor resources, an expert commission was formed, which included: Director of the Department of Economic and Regional Development of Kherson Regional State Administration; Head of the Human Resources Department of the Main Directorate of the State Fiscal Service of Ukraine in Kherson Oblast, Autonomous Republic of Crimea and Sevastopol; Head of the Department of Management and Administration of Kherson State University; Chairman of the Kherson Regional Inter-branch Council of Trade Unions; Chairman of the Board of the NGO "Business Association "WE-Kherson".

In the Table. 2 summarizes the expert group's recommendations on the indicators to be taken into account when

\begin{tabular}{|c|c|c|c|c|c|c|c|}
\hline \multirow{2}{*}{$\begin{array}{l}\text { call } \\
\text { number }\end{array}$} & \multirow{2}{*}{ Indicator } & \multicolumn{6}{|l|}{ Years } \\
\hline & & 2013 & 2014 & 2015 & 2016 & 2017 & 2018 \\
\hline \multicolumn{8}{|c|}{ Efficiency of use of labor resources } \\
\hline A1 & $\begin{array}{l}\text { Admission workforce turnover } \\
\text { ratio }\end{array}$ & 0.209 & 0.416 & 0.208 & 0.416 & 0.208 & 0.312 \\
\hline $\mathrm{A} 2$ & Displacement turnover factor & 0.313 & 0.104 & 0.313 & 0.312 & 0.208 & 0.104 \\
\hline A3 & $\begin{array}{l}\text { Coefficient of total labor } \\
\text { turnover }\end{array}$ & 0.522 & 0.520 & 0.521 & 0.728 & 0.416 & 0.415 \\
\hline A4 & Labor turnover ratio & 0.313 & 0.104 & 0.208 & 0.312 & 0.208 & 0.104 \\
\hline A5 & $\begin{array}{l}\text { Average monthly salary of staff, } \\
\text { UAH / person }\end{array}$ & 3018.94 & 4074.41 & 4574.89 & 4678.74 & 5974.37 & 6507.84 \\
\hline A6 & $\begin{array}{l}\text { Productivity of personnel, } \\
\text { thousand UAH / person }\end{array}$ & 15092.7 & 18748.3 & 22748.9 & 25967.3 & 30745.8 & 37489.2 \\
\hline
\end{tabular}
assessing labor efficiency.

Table 2. Generalized recommendations of the expert group on indicators that need to be taken into account when assessing the efficiency of use of labor resources

In the table 3, the mean value and standard deviation were calculated for a group of indicators characterizing the efficiency of labor utilization 
Table 3. Calculation of mean and standard deviation

\begin{tabular}{lllllllll}
\hline Indicator & 2013 & 2014 & 2015 & 2016 & 2017 & 2018 & $\mathrm{~A}$ & $\delta$ \\
\hline A1 & 0.209 & 0.416 & 0.208 & 0.416 & 0.208 & 0.312 & 0.295 & 0.093 \\
A2 & 0.313 & 0.104 & 0.313 & 0.312 & 0.208 & 0.104 & 0.226 & 0.094 \\
A3 & 0.522 & 0.520 & 0.521 & 0.728 & 0.416 & 0.415 & 0.520 & 0.104 \\
A4 & 0.313 & 0.104 & 0.208 & 0.312 & 0.208 & 0.104 & 0.208 & 0.085 \\
A5 & 3018.94 & 4074.41 & 4574.89 & 4678.74 & 5974.37 & 6507.84 & 4804.9 & 1159.0 \\
A6 & 15092.7 & 18748.3 & 22748.9 & 25967.3 & 30745.8 & 37489.2 & 25132.0 & 7440.1 \\
\hline
\end{tabular}

Standardized indicator values, intermediate values of the reference point, Euclidean distance and integral indicator are shown in table 4.

Table 4. Standardized values of indicators, intermediate values of a reference point, Euclidean distance and integral index

\begin{tabular}{|c|c|c|c|c|c|c|c|c|c|c|}
\hline The default value & 2013 & 2014 & 2015 & 2016 & 2017 & 2018 & $\begin{array}{l}\text { Reference } \\
\text { point }\end{array}$ & $\overline{C_{0}}$ & $C_{0}$ & $\mathrm{~S}_{0}$ \\
\hline $\mathrm{A} 1$ & -0.9211 & 1.3002 & $\begin{array}{l}- \\
0.9318 \\
\end{array}$ & 1.3002 & $\begin{array}{l}- \\
0.9318 \\
\end{array}$ & 0.1842 & -0.9318 & & & \\
\hline $\mathrm{A} 2$ & 0.9325 & $\begin{array}{l}- \\
1.2991\end{array}$ & 0.9325 & 0.9218 & $\begin{array}{l}- \\
0.1886\end{array}$ & $\begin{array}{l}- \\
1.2991\end{array}$ & -1.2991 & & & \\
\hline $\mathrm{A} 3$ & 0.0160 & $\begin{array}{l}- \\
0.0032 \\
\end{array}$ & 0.0064 & 1.9935 & $\begin{array}{l}- \\
1.0016 \\
\end{array}$ & -1.0112 & -1.0112 & & & \\
\hline A4 & 1.2316 & $\begin{array}{l}- \\
1.2238 \\
\end{array}$ & $\begin{array}{l}- \\
0.0020\end{array}$ & 1.2198 & $\begin{array}{l}- \\
0.0020\end{array}$ & $\begin{array}{l}- \\
1.2238 \\
\end{array}$ & -1.2238 & & & \\
\hline A5 & $\begin{array}{l}- \\
1.5409 \\
\end{array}$ & $\begin{array}{l}- \\
0.6302 \\
\end{array}$ & $\begin{array}{l}- \\
0.1984 \\
\end{array}$ & $\begin{array}{l}- \\
0.1088 \\
\end{array}$ & 1.0091 & 1.4693 & 1.4693 & & & \\
\hline A6 & $\begin{array}{l}- \\
1.3494 \\
\end{array}$ & $\begin{array}{l}- \\
0.8580 \\
\end{array}$ & $\begin{array}{l}- \\
0.3203 \\
\end{array}$ & 0.1123 & 0.7545 & 1.6609 & 1.6609 & & & \\
\hline Euclidean distance & 5.4943 & 4.0928 & 3.7703 & 5.4592 & 1.9389 & 1.116 & & 3.6453 & 4.0291 & 11.7035 \\
\hline $\begin{array}{l}\text { The integral } \\
\text { indicator }\end{array}$ & 0.53 & 0.65 & 0.68 & 0.53 & 0.83 & 0.9 & & & & \\
\hline
\end{tabular}

In Fig. 3 we will present the results of determining the integral indicator of estimation of the efficiency of use of human resources for 2013-2018.

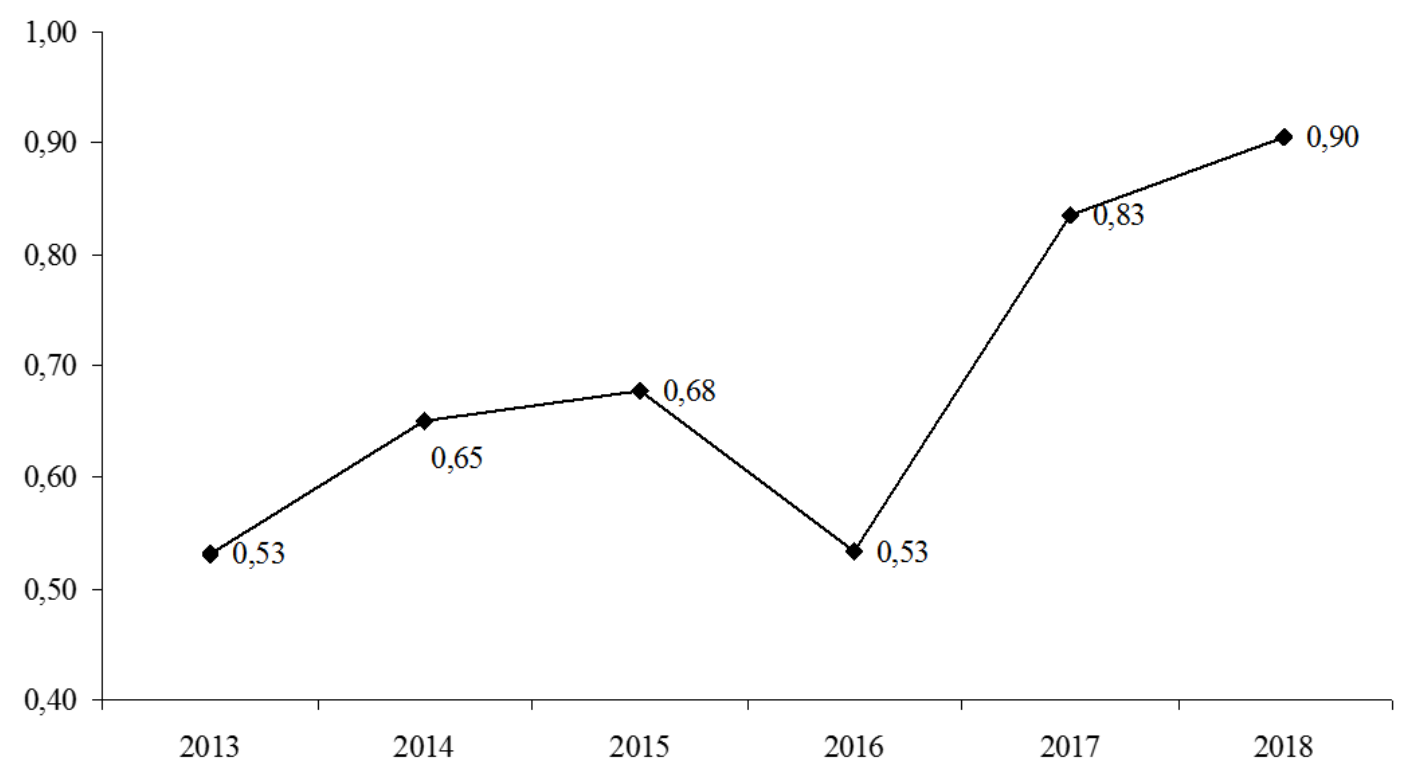

Figure 3. Integral indicator of estimation of efficiency of use of labor resources for 2013-2018 
The results show that the main decrease in the integral index occurred in 2013 and 2016, which is directly related to the high level of total labor turnover and staff turnover. This is due, above all, to low pay while having a relatively high level of productivity. For example, in 2016 labor productivity was almost 5.6 times higher than the level of given wages.

\section{Conclusions and Recommendations for the Further Research}

The results of the study indicate the need for the formation of an innovative enterprise competitiveness management system, which should be based on the principles of priority of innovative, developed, scientific novelty, a feasibility study, legal justification, minimizing risk and increasing the competitiveness of both products, works, services, and the enterprise as a whole. The innovative activity of enterprises, including healthcare institutions, in the conditions of an unstable internal and external business environment is the main condition for their competitiveness and requires system management.

It was revealed that the basis of the innovative approach to managing healthcare institutions should be systemic transformations in the industry that combine the formation of an innovative infrastructure, an innovative financial and economic mechanism, as well as accounting, analytical, regulatory, methodological and information support, that will improve the quality and accessibility of medical assistance and efficient use of health resources.

To achieve the proper level of competitiveness, participants in the innovation process must constantly develop and implement appropriate innovation development strategies. The development of competitive strategies makes it possible to obtain sustainable competitive advantages through intense competition, to satisfy the needs of consumers of medical services based on innovative technologies better than competitors do. At the same time, one of the most important components in the development and justification of the feasibility of implementing competitive strategies for an objective assessment of the level of competitiveness of the enterprise as a whole and its individual components in particular.

Thus, the study to determine the integral indicator of assessing the efficiency of labor use has led to the conclusion that the leadership of the health care institution under study must first develop measures, that will help eliminate the negative values of certain indicators and help improve the personnel management system. In order to introduce an effective model of personnel management in healthcare institutions, it is very important to provide the main criteria for evaluating its effectiveness at the stage of formation. This is very complex, especially in the Ukraine forum before evaluating the effectiveness of the personnel management model in general, and not just its individual storage. The personnel management model has an emphasis on intellectual, social, organizational and other warehouses.

The mechanism of determining the coefficient of competence of experts involved in the evaluation of staff, taking into account their work experience, the scale of management activity, and the level of education, deserves further study. This will maximize the effectiveness of the rating and coordinate the efforts and resources of employees to improve defined and relevant for the enterprise.

\section{References}

Adair, P., \& Adaskou, M. (2018). The capital structure of mature French SMEs and impact of the great recession: A dynamic panel data analysis (2002-2010). Economics, Management and Sustainability, 3(2), 60-75. https://doi.org/10.14254/jems.2018.3-2.5

Akhlamov, A. H., \& Kusyk, N. L. (2011). Health Economics and Financing: A Learning Method. tool. Odessa.

Andreeva, Y. L. (2009). A model for optimizing the implementation of scientific results in health care practice. Volgograd Bulletin. state. honey. universities, 4, 23-29.

Androshchuk, H. O., \& Zhyliaiev, I. B., \& Chyzhevskyi, B. H., \& Shevchenko, M. M. (2009). Ukraine's Innovation Development Strategy for 2010-2020 in the face of globalization challenges. K: Parliamentary view.

Beliakov, V. K., \& Pyven, D. V., \& Antonov, D. P. (2008). On the problems of innovation policy in domestic health care and the need to create clusters of medical innovations. Management in Health, 3, 4-11.

Bell, M., \& Pavitt, K. (1997). Technological accumulation and industrial growth: contrasts between developed and developing countries. W: D. Archibugi, J. Michie (red.). Technology, globalization and economic performance. Cambridge: Cambridge University Press.

Bilovodska, O. A. (2017). Marketing distributive and sales policy: research of essence, role and importance. Marketing and Manadgment of Innovations, 2, 85-97. http://doi.org/10.21272/mmi.2017.2-08

Bilynska, M. M. (2002). Methodology for Building a National Quality Management System for Higher Medical 
Education. Contemporary City Management, 7(9), 155-160.

Bodak, V. M. (2004). Problems of information support of processes of management of development of family medicine. Bulletin of Soc. hygiene and health organizations of Ukraine, 1, 72-77.

Bohdaniuk, I., Kolisnichenko, V., \& Ustymenko, O. (2018). Audit as a form of control of the state financial inspection of Ukraine. Baltic Journal of Economic Studies, 4(5), 31-35. https://doi.org/10.30525/22560742/2018-4-5-31-35

Bruneel, J., Ratinho, T., Clarysse, B., \& Groen, A. (2012). The evolution of business incubators: Comparing demand and supply of business incubation services across different incubator generations, Technovation, 32(2), 110-121. https://doi.org/10.1016/j.technovation.2011.11.003

Burkynskyi, B. V., Lazareva, E. V., \& Aheeva, Y. N. (2002). Competitiveness of products and enterprises: Monohrafyia. Odessa: Institute of market problems and economical ecological researches of the NAS of Ukraine.

Byrher, E. V. (2007). Information and telecommunication technologies in health care. M.: Ritex.

Capello, R., Caragliu, A., \& Nijkamp, P. (2009). Territorial Capital and Regional Growth: Increasing Returns in Cognitive Knowledge Use. Tinbergen Institute Discussion Paper. TI 2009-059/3. https://doi.org/10.2139/ssrn.1443830

Cepel, M., Stasiukynas, A., Kotaskova, A., \& Dvorsky, J. (2018). Business Environment Quality Index in the SME Segment. Journal of Competitiveness, 10(1), 21-40. https://doi.org/10.7441/joc.2018.02.02

Cherunilam, F. (2010). International business: text and cases. New Delhi: PHI Learning Pvt. Ltd.

Edquist, C. (2004). Systems of Innovation - A Critical Review of the State of the Art. W: J. Fagerberg, D. Mowery, R. Nelson (red.), Handbook of Innovation. Oxford: Oxford University Press.

Feigenbaum, A. V., \& Feigenbaum, D. S. (2009). The power of management innovation: 24 keys for sustaining and accelerating business growth and profitability. New York: McGraw-Hill.

Ivanová, E., \& Čepel, M. (2018). The Impact of Innovation Performance on the Competitiveness of the Visegrad 4 Conutries. Journal of Competitiveness, 10(1), 54-72. http://dx.doi.org/10.7441/joc.2018.01.04

Karamyshev, D. V., \& Nemchenko, A. S. (2006). Implementation and evaluation of the effectiveness of innovative projects in the healthcare system. Economy and State, 2, 86-88.

Ključnikov, A., Kozubíková, L., \& Sopková, G. (2017). The Payment Discipline of Small and Medium-sized Enterprises. Journal of Competitiveness, 9(2), 45-61. https://doi.org/10.7441/joc.2017.02.04

Klymenko, S. M., Dubrova, O. S., Barabas, D. O., Omelianenko, T. V., \& Vakulenko, A. V. (2006). Management competitiveness of enterprise. Retrieved from http://posibniki.com.ua/catalog-upravlinnyakonkurentospromozhnistyu-pidpriemstva---klimenko-sm

Ko, H., \& Min, K. (2019). Determinants of social expenditures in post-socialist countries. Economics and Sociology, 12(2), 253-264. https://doi.org/10.14254/2071-789X.2019/12-2/15

Kozubikova, L., Kotaskova, A., Dvorsky, J., \& Kljucnikov, A. (2019). The impact of political factors‘ perception on suitability of international business environment: The case of startups. Economics and Sociology, 12(1), 61-79. https://doi.org/10.14254/2071-789X.2019/12-1/3

Lepetiukha, N. V., \& Rudska, I. O. (2016). The Integral Estimation of the Enterprise Functioning. Nikolaev National University of VA Sukhomlinsky. Business Economics and Management, 14, 424-429.

North, D. (1991). Institutions. Journal of Economic Perspectives, 5(1), 97-112. https://doi.org/10.1257/jep.5.1.97

Pashkov, V. D. (2006). State Policy for Social Innovation in Health. Pharmacy, 37(558). Retrieved from http://www.apteka.ua/article/3647

Porter, M. (2005). Competition; trans. with English. M.: Williams Publishing House.

Savchuk, A. V. (2001). A systematic approach to the analysis of the competitiveness of an industrial enterprise. Economist, 12, 58-61.

Skurativskyi, V. (2003). Humanitarian, social and economic priorities of innovative development of Ukraine. Bulletin of UADU, 2, 374-379.

Spasibo-Fatieieva, I. (2005). The Legal Aspect of Innovation in Ukrainian Realities. Bulletin of the Academy of Legal Sciences of Ukraine, 4, 15-23. 
Tsymbaliuk, S. O. (2017). Determinants of personnel labor activity within the system of motivation. Actual problems of economics, 187, 264-272.

Tyukhtenko, N. A., \& Makarenko, S. M. (2016). Economic and mathematic models for staff planning at enterprises of all ownership forms. Actual problems of economics, 175, 435-442.

Zachosova, N. (2019). Innovative approach in the estimatology of financial institutions economic security: possibilities of use in management and regulatory activity within the means of provision of the state financial security. Baltic Journal of Economic Studies, 5(2), 45-56. https://doi.org/10.30525/2256-0742/2019-5-2-4556

\section{Copyrights}

Copyright for this article is retained by the author(s), with first publication rights granted to the journal.

This is an open-access article distributed under the terms and conditions of the Creative Commons Attribution license (http://creativecommons.org/licenses/by/4.0/). 